\title{
CULTURAL HERITAGE AS A DRIVER FOR URBAN REGENERATION: COMPARING TWO PROCESSES
}

\author{
ANDREA BOERI, GIULIA BORTOLI \& DANILA LONGO \\ Department of Architecture, University of Bologna, Italy
}

\begin{abstract}
This paper focuses on the international research-action activities conducted by a team from the University of Bologna, Italy, and on a methodological approach applied to the city, understood as heritage and common good. The premise establishes Cultural Heritage as the main field of research-action, which is not intended as a static presence in the city, but, at best, should be constantly updated with the actions of transformation of the city. The cultural model is based on a continuous effort to recognize the city and its transformations as heritage, combining conservation and innovation in a seamless stream and permanently involving not only heritage specialists but also all actors that are involved in urban transformation, with varying degrees of responsibility and awareness. Two cities are considered as references and compared with each other to study and test this approach: Bogotá and Bologna, with, respectively, two important historical areas, Carrera Séptima and Zamboni district. The focus is on the role that the cultural heritage, material and immaterial plays in the current urban landscape and on its potential to be a driver for regeneration in the degraded urban fabric. Both areas have been crucial to urban development and to the expression of social needs by the population, becoming a symbol of collective identity, for better or worse. Since the first half of the 20th century, Bogotá has experienced an exponential urban growth process, triggering wearing dynamics that have compromised the urban architectural heritage preservation of the city and led to progressive historical city center deterioration. Bologna district, on the other hand, hosts the oldest university in the western part of the world, and having such a strong function in a compact city center reality has caused coexistence and social problems, as well as integration needs, among the different users. The two historical realities are studied using a comparative methodology, one as a typical European city and the other as a Latin American megalopolis. In this light, the term "street" is not limited to the description of the physical space, but is associated with the whole system of connections and influences that they exert on their own area.
\end{abstract}

Keywords: cultural heritage, common good, collective identity, historical city center, regeneration process, urban growth.

\section{INTRODUCTION}

The debate on the cultural heritage and historical center of cities today is of international importance, and is central for current urban planning. The transformation processes of the urban territories impose new challenges and the need to find new answers and strategies that are valid in the environmental, cultural, social and economic fields.

Culture, and cultural heritage in general, is a cross-cutting resource capable of activating models of territorial development that hold sustainability as their main objective. Cultural heritage could be an active tool to regenerate problematic urban fabrics, creating new flows that strengthen urban areas from the social and economic point of view. Historical territorial tissues are very important for individual communities because of collective memory and identity. This goes beyond the material goods, referring to the intangible dimension of a place representative for the community.

Particular attention to public spaces as spaces for the community has been paid in the interaction of actors of the urban scene, in places characterized by tensions and discomforts. New policies, aimed at the introduction of good practices and creative processes based on the 
evocative power of cultural heritage, can lead to the rediscovery of public space and suggest a new scenario of life and integration. Cultural heritage, therefore, is an ongoing creative process - not as an element of rigidity or as an obstacle to the city's transformation - where the citizens themselves are the actors. The involvement of the main public and private stakeholders, active participation of the population and correct planning are crucial in directing this regeneration process [1].

Based on these considerations, the study looks at two worlds - Bogotá and Bologna case studies - according to two different models - the historical center in Latin America and the relationship between the historical center and the presence of university and its students in Europe - to present the debate on how urban regeneration driven by cultural heritage is a priority in the urban agenda. On the one hand, the activation of new flows can change destructive dynamics that compromise the free use and attractiveness of urban spaces; on the other, the action on the physical space can allow orientation and accessibility, to enjoy the stimulus of the Agora model, mitigating its confusion [2]. This study refers to a common project by the University of Bologna and Universidad Nacional de Colombia, which aims to develop and consolidate relations through shared researches in real cases. In particular, the research reported in this paper is based on an inter-disciplinary method defined in the Joint-Lab Bologna-Bogotà, a transnational atelier based in the two cities aimed at promoting, at international level, the research-action activities applied to the city considered as heritage and common good. The lab establishes Cultural Heritage as the main field of research-action, not intended as a static presence in the city, but as a set of actions to transform the city. The cultural model of reference is based on a continuous effort to recognize the city and its transformations as heritage, supporting, at the same time, conservation and innovation, and permanently involving not only the heritage specialists but also all of the local actors directly or indirectly involved in urban transformation, with varying degrees of responsibility and awareness.

The two-universities approach is based on thematic workshops involving researchers, students and $\mathrm{PhD}$ students, looking at specific cities' areas and dealt with from different points of view, to define a coherent proposal and vision for the future. In this specific case, the two universities were connected with two specific areas. The analysis and the literature review were based on two layers: the description of the current debate about heritage and historical city center conditions; a focus on the areas using the same parameters to describe their frameworks (meanings, dynamics and problems); and current urban regeneration plans in relation to heritage. The first is mainly based on international UNESCO and ICOMOS conferences, charters and documents, and the second one on studies, Urban Living Labs reports and urban plans drawn up by the main stakeholders of each area (University of Bologna teams, Bologna and Bogotá Municipality, "ROCK Project" - Horizon 2020 EU-founded project).

\section{BEHIND THE CONCEPT OF "CULTURAL HERITAGE”}

The meaning associated with the concept of cultural heritage has widened over time and now includes an ever-increasing number of aspects and elements, expressing its universal value. Its definition goes beyond the material dimension of a single monument or the urban/environmental system, and into the intangible dimension, including those elements practices, representations, expressions, knowledge, skills - recognized by a community as an integral part of their identity [3]. The evolution of the cultural heritage concept has been a very long process, born in the first half of the 20th century as a reflection on the preservation of the historic city. A series of international documents show both the centrality of the theme at world level and the shift from a local to a global dimension. The result was the change in 
the policies of approach to heritage (from a conservation policy to an enhancement one) where innovative intervention is a condition to update the heritage and ensure its full integration into the context. Italy was a pioneer in this process and has exported an intervention model to the world for the preservation and modification of the historic city (Venice Charter, 1964) [4]. In this step, "cultural heritage" is meant as a single monument (or urban system as a network of monuments), and the concept is widely overtaken by the Recommendation of Nairobi (1976) and the Washington Charter (1987). Now, the "historical city" is interpreted as the sum of the natural and built environment and their spiritual values (link between material and immaterial dimension); this includes the totality of urban spaces (including public space) and it needs the active involvement of citizens for its protection. The historic city extends its boundaries and seeks ways to fight the consequences - the degradation and destruction - of urbanization that began in the industrial era [5]. The UNESCO Recommendation on the Historic Urban Landscape (2011) defines the HUL (general urban context and its geographical surroundings as historical stratification of cultural, social and natural values) and, for the first time, talks about the link between cultural heritage and sustainable development, underlining the opportunity to adapt the heritage to the needs of the contemporary society. In a scenario in which cities have a dynamic character, urban heritage is a resource for improving the liveability of urban areas, economic development and social cohesion. The challenge is to turn conservation into the main strategy of regeneration and sustainable growth; it is necessary to develop adequate evaluation methods, business, management and financing tools, engaging civil society and local stakeholders [6]. In the Paris Declaration On Heritage as a Driver of Development (2011), "sustainable development" is defined, referring to Article 3 of the UNESCO Universal Declaration on Cultural Diversity (2001): "development, understood not only in terms of economic growth, but also as a means to achieve a more satisfactory intellectual, emotional, moral and spiritual existence" [7]. The Hangzhou Declaration (2013) was the result of the very first global forum to discuss the role of culture in sustainable development in view of the post-2015 development framework. In the section, Harness culture as a resource for sustainable urban development and management, it says: "Culture-aware policies in cities should promote respect for diversity, the transmission and continuity of values, and inclusiveness by enhancing the representation and participation of individuals and communities in public life and improving the conditions of the most disadvantaged groups". It also emphasizes the civic role of cultural infrastructures and the importance of culture in the redevelopment of urban areas, especially public spaces, "to preserve the social fabric, improve economic returns and increase competitiveness, by giving impetus to a diversity of intangible cultural heritage practices as well as contemporary creative expressions" [8]. The New Urban Agenda (2016) implements the combination of good urbanization development and, according to the 2030 Agenda for Sustainable Development (objective 11), wants cities and human settlements to be "inclusive, safe, resilient and sustainable", and perceives culture and cultural diversity as "sources of enrichment for humanity" and incentives for the sustainable development of cities [9]. A positive result involves all the actors who can help to create an appropriate urban planning strategy where the participation of citizens is put first and where heritage is a "common good".

The Urban Living Lab is a new cooperation and participatory model to promote urban regeneration, based on a systematic user co-creation approach in public-private-people partnerships, focused on solving a particular problem, through circular actions aimed at implementing sustainable technologies and processes in real-life communities and settings [10], [11]. This model involves the implementation of small-scale tests, usually in a limited urban area, their uptake across the city and their replicability in other cities. The activation 
of this virtuous path for urban resilience has positive influences in the city area (environmental, economic and social dimension).

Culture is recognized as a new resource for the development of a territory, but the question is, how to organize it in order to start this process? A possible model is the "cultural district" model [12] - a space with ideal boundaries and strong identity vocation where the connection between the cultural sector and local production systems generates socio-economic development. The next level is the evolved cultural district model, where the relationship between culture, creativity and innovation is the pillar, and where cooperation between cultural operators, public administrations, the business world, civil society and the university world is necessary.

Imagining portions of historical cities as ideally bounded leads to a focus on creating porous margins - membranes intended as places of exchange with cultural tensions in which the citizen is called to a daily task, i.e. the transition experience. The city and its "liminal" edges create a sort of "transition awareness", in a continuous passage between the places and their dynamic tensions - an open city that allows us to identify its characteristic and characterized edges [2].

\section{PLACES, MEMORY AND COLLECTIVE IDENTITY}

The city, as a product of a dynamic and articulated process over time, contains the physical testimonies of the transformations and changes that it has experienced. According to Calvino [13], "The city (consists of) relationships between the measurements of its space and the events of its past. The city however does not tell its past, but contains it like lines of a hand". Its strength lies in its ability to be a vessel of the past - as material and immaterial heritage - and, for this, the city may be defined as a place of historical, cultural and social memory of the population. Past, heritage and memory, therefore, enshrine the close link between the urban space and its inhabitants and play an important role in the construction of collective identity. The historical center's main value is in its urban spaces; there are both the memory of neighborhood and the urban memory - i.e. the concrete dimension of everyday life and the ideological one of the foundational place of the whole city (Bossio et al. [14]).

According to Carrión [15], the nature of the historical center is to be the public space par excellence, where urban tensions between state and society and between public and private sectors take place and where the symbiosis, the symbolic and the polis coexist. The historic center is a place for meeting, integration and community discussions; it is a place for heterogeneity and for exercising citizenship. The historical center's public-space identity leads us to the understanding that it is impossible to separate the built environment from the empty spaces between the buildings; not residual spaces, but an integrated system of networks and connections in which each element is a fundamental part of the urban fabric. In the same way, the space must be thought of in relation to population, social function and role in the collective imagination. The public space, as "in-between", separating and joining the people at the same time and creating a playing field where the heterogeneity of the perspectives that reside there, is the condition to assert the one's own individuality [2], [16]. However, not all spaces have the same value and the same weight in the memory of its inhabitants; the population assigns a symbolic value to particular places, identifying with those that were the background to meaningful events in urban life. The identity of these places can be a double-edged sword, excluding those who do not identify with its values [17]. Public space has an "affective" value, which leads its users to live in the space "privately", according to the individual relationships with it, until there is a misuse of the space. Public space projects cannot ignore, therefore, the inclusion of citizenship and the role of the location in people's imagination and life [14]. 


\section{CASE STUDIES: BOLOGNA AND BOGOTÁ}

The research by Bologna and Bogota teams helps develop the issues previously addressed (cultural heritage as a source of territorial development, identity of places and role of public space in the life of citizenship) in reference to two historical city center areas: the case study of Carrera Séptima in Bogotá, and the Zamboni cultural district of Bologna. These case studies represent two realities (Latin American megalopolis and the European city) with a different historical-cultural, socio-economic, political and geographical background; however, both share common problems regarding the enhancement of historical centers [14].

The boundaries include areas with cultural value, heterogeneity of uses and identity: the Bogotá area is linked to the planned pedestrian space in Carrera Séptima [18] and includes the historic sites of La Candelaria and part of Santa Fe (part of PEMP area [19]); the Bologna area is linked to the Zamboni cultural district (northeast corner of the city).

Bogotá dynamics are related to the Latin American metropolis changes: uncontrolled urbanization, planning, political interests and building speculation added to the issues of historic center "ghettoization", security, illicit appropriation of public space and mobility, have compromised the preservation and use of cultural heritage [15].

Bologna dynamics are related to the city-university relationship: from the beginning, the history and development of the European universities are linked to those of the urban fabrics where they are located ("widespread campus" model). In cities with a long academic tradition, the two-way link between academy and city leads to an economic, cultural and social development, and a continuous exchange of knowledge, resources and human capital [20]. The university, in addition to its positive contributions, can also cause imbalances between the student world and the other users' daily-lives (residents, workers, tourists) [21].

Both areas show two opposite logics: urban degradation (marginality, devaluation, invasion of public space, high-impact activities) and, on the contrary, the historical and cultural urban value (built heritage, cultural and educational activities).

\subsection{Case studies: the meaning for the city}

At the center of the case studies, there are two streets - Carrera Séptima and Via Zambonirepresenting structural axes and symbolic places. Their meaning and current condition both in the city and, in particular, in the area of influence can be understood by knowing the urban history and development and the important events that have happened here.

\subsubsection{Carrera Séptima and Bogotá historical centres}

The history of Bogotá begins with colonial events in the 16th century (1538 year of establishment). The Carrera Séptima is the historical street along which the city has developed and shares the past and present with the historic center. For these reasons, it has a historical and cultural, political, social and economic value [22], [23]:

- Historical-cultural: the historical center contains the most representative buildings. Buildings placed on Carrera Séptima show all the historical phases and its changes (colonial, republican and modern age). The Carrera Séptima maintains its function as a structural axis in urban expansion from the colony to urbanization (early 1900s) and it is the main link to the city (tramway Bogotá-Chapinero, 1884-1948). There are a lot of cultural buildings in this area.

- Political: the historic center maintains its representative function. The Carrera Séptima is the most representative axis of political power. It is the main residence for dialogue 
between institutions and citizenship, and has hosted scenarios that are included in the country's most dramatic events (e.g. Bogotazo, April 9, 1948).

- Social: the historical center hosts a heterogeneity of uses, functions, activities and users. The Carrera Séptima has welcomed all social classes, both on working days and on public holidays (Septimazo), since the time of the colony. Between the 1930s and 1940s the socio-economic separation between the north (residential districts) and the south (workers' quarters) of the city determined the abandonment of the center by the upper class.

- Economic: the historical center has been the main residence for commerce throughout history. The Carrera Séptima has been named "Calle Real Del Comercio" (colonial period).

\subsubsection{University and Zamboni district}

The Alma mater studiorum University of Bologna is the oldest university in the Western world (established in 1088). Via Zamboni is a historic university street (since 1804) with historical and cultural, political, social and economic value [24], [25]:

- Historical and cultural: Via Zamboni is an ancient noble street, once occupied by the old palaces of Bologna and their noble families (15th century). Plus, the Opera House was built in 1763 as the first "public" opera house in Europe.

- Political: the university has influenced the politics of the city from the beginning (Costitutio Habita 1158). The university has become, in time, a place animated by political ferment, where clashes between the student and the political system have taken place (moving into the urban scene in 1977: barricades in the university district, armed police-student clashes) and still persist; the first forms of aggregation and self-management centers have also been experimented with here. Currently, the theme of the relationship with the university is one of the most sensitive for public policies.

- Social: the district has always been an example of heterogeneous cohabitation by hosting figures linked (directly or indirectly) to the university world. They share and mix their ways in a particular meeting place, the Piazza Verdi and the porticoes. Today, this social heterogeneity is causing problems and clashes at the level of the city as a whole.

- Economic: the university's presence has caused the economic growth of the city, but it has also conditioned the district's commercial opportunities (for university customers only).

\subsection{Case studies: dynamics and problems}

The case studies present the same conditions, in respect to their own problems:

- a continuous change of urban scenarios during the day: large and heterogeneous flow during daylight hours, and residential vocation at night (the area is depopulated and the distribution of flows focuses on specific sites or reduced just to members of the micro-criminality and homeless people);

- marginalization of the areas because of their prevailing reality (popular and university reality);

- difference between the historical-cultural value and the social and spatial conditions of public and private space. 
4.2.1 Carrera Séptima and Bogotá historical multifunctionality and social strata

The Bogotá historic center is beset by numerous problems as shown by the various districts analysis. In particular, based on the analysis conducted by the last two administrations (Gustavo Petro Administration 2012-2015 and Enrique Peñalosa Administration 2016-2019) [19]-[26] and on the result of PEMP co-creation activities (March 2018) [19], the following problems can be found: difference between residential reality and commuter reality; insecurity and invasion of public space; degradation of cultural assets (with associated recovery, conservation and management cost of cultural assets); and disregard of the patrimonial value by the population.

The plurality of functions (administrative, cultural, commercial and receptive) attracts a large flow of commuters (public officials, workers, students and tourists) every day, which, in turn, constitutes an opportunity for the growth of activities related to the informality world, attracting a different kind of people (street vendors and micro-criminals). There are also the "fixed" presences (residents and inhabitants of the street) that determine the popular character of the area (trade and quality of services) due to their economic condition (medium-low social class). Insecurity and invasion of public space (street sales, the presence of homeless people, micro-traffic, drug use, prostitution, etc.) are serious issues for the population (resident or not), negatively affecting the imaginary urban space and contributing to an increased perception of degradation, and becoming a deterrent for the usability of the area, especially at night. The neglect and deterioration state of the fixed heritage is in conflict with its historical-cultural value and makes the urban scenario even worse.

Carrera Séptima is emblematic of this condition, showing the heterogeneity of the situations and users. A questionnaire published in 2014 [27] underlines the use, looking at the perceptions and relationships that users have with the road. The majority of participants $(84 \%)$ consider it the preferential transit link of the historical sector, and more than half $(68.51 \%)$ are attracted by its cultural assets (historical sites, street artist shows, theaters, cinemas and museums), compared to the attractiveness of trade (formal and informal) or the restaurant sector. The meanings associated with the road are linked to the users' socio-economic condition: low-level users $(76.9 \%$ of total users) connect it to the "septimazo", and high-level users, to the history.

\subsubsection{Zamboni district: mono-functionality and social problems}

The Zamboni district presents numerous problems, the management of which is a priority for the public administration and involves a large number of actors (municipalities, universities, cultural institutions, resident and student associations, etc.). Referring to research by Tolomelli et al. [25] and to the U-Lab practices [28], the following problems have emerged:

- Conflicts between the student population and residents;

- Mono-functionality of the area and limited attractiveness in the commercial and recreational offer;

- Cultural assets not accessible to all users;

- Appropriation of public space, unrest and insecurity;

- Inadequacy of urban furniture.

Many users (students, workers, tourists and residents) attend Zamboni district daily, and the students comprise the largest portion. Their presence conditions the rhythms of life and the activities (formal and informal) of the whole area. The first problem concerns their cohabitation with the residential population because of their different conditions (lifestyles, priorities, needs, etc.). On a common spatial level, these differences concern the times and 
ways of living the public space: students stay in the district until night, appropriating the area and creating inconvenience with their socialization practices (bivouac, noise, disturbance of public peace, presence of waste, etc.). The commercial and recreational assets (low cost and low quality) target student consumers, specializing in fast food and finger food, which is not attractive for a large number of users. The cultural offer is at a high level and heterogeneous, but it is no accessible to all users, not respecting the prerogative of a cultural district (culture element of development). The social outcasts (drug addicts and homeless), who have lived in the area since the 1980s and 1990s, settle in some areas of the public space, affecting its usability. Their presence and that of students attract the flow of petty crime and micro-trafficking (the illegal sale of alcohol, theft of bicycles, drug dealing and drug use, etc.) that can make the area insecure and seen as "degraded". Inadequate urban furniture (the lack of or inappropriate lighting, etc.) and chaotic paths (pedestrian, bicycle and motor traffic) worsen the perception of insecurity and disorder.

\section{CASE STUDIES AND HERITAGE: POLICIES AND STRATEGIES}

\subsection{Past and present policies for the heritage of Bogotá}

In Latin America, raising awareness for the protection of heritage and its affirmation in national legislation has a longer history than in Europe [4]. Law 163 (1959) for Bogotá was the first to give importance to the theme (zoning and isolation of historic center area and classification of buildings). The Decree No. 264 of 1963 integrates article 4 of the law and declares the historical center of Bogotá a National Monument [28].

Since the 1920s, the phenomenon of urbanization and the question of car mobility have imposed new urban planning requirements with consequent changes in the urban structure and causing damage to the architectural heritage (Karl Brunner Von Lehenstein's planning, Le Corbusier's Plan Piloto 1949, Wiener and Sert's Plan Regulador 1951-1952) [20]. Bogotazo (April 9, 1948) was crucial for attacks on the architectural heritage and the future of the historic center (136 buildings burned, depopulation of the center, construction of new buildings far from context, tradition and meeting the laws of the market). Since the 1970s, the drive for the protection of heritage has intensified and has laid out the foundations for the establishment of plans and institutions that currently regulate and manage the heritage (Corporación La Candelaria 1980, POT 1990, IDPC 2006). There were numerous studies and plans aimed at the redevelopment of the center (Plan Centro de Fonade, Plan Reencuéntrate con la Candelaria, Plan de Revitalización del Centro Tradicional) that were never completed [19], [20].

Today, the protection and valorization of heritage and the idea of historic center renovation seem to be a priority for the city's government. In 2016 the IDCP formulated the Plan Especial de Manejo y Protección (PEMP), a tool for the management of cultural heritage, to "recognize, claim, revitalize and recover the city center" until 2050. The first step defines the historical center's boundaries (larger than the perimeter of the La Candelaria locality, as mentioned by Mauricio Uribe, IDPC director). The central area (Fig. 1) includes three localities (Los Mártires, Santa Fe and La Candelaria) for a total of 135,000 residents, 1-2 million commuters and 2371 people of fixed heritage (37\% Bogotá BIC). The IDPC director claims the importance of historical memory and that of the active role of citizens for its preservation. A participatory policy (PEMP-CH co-creation activity) was promoted to involve citizens and make them aware of the value of heritage, by encouraging a dialogue between residents, the public sector, private organizations, universities, students, visitors and other users [19]-[30]. 


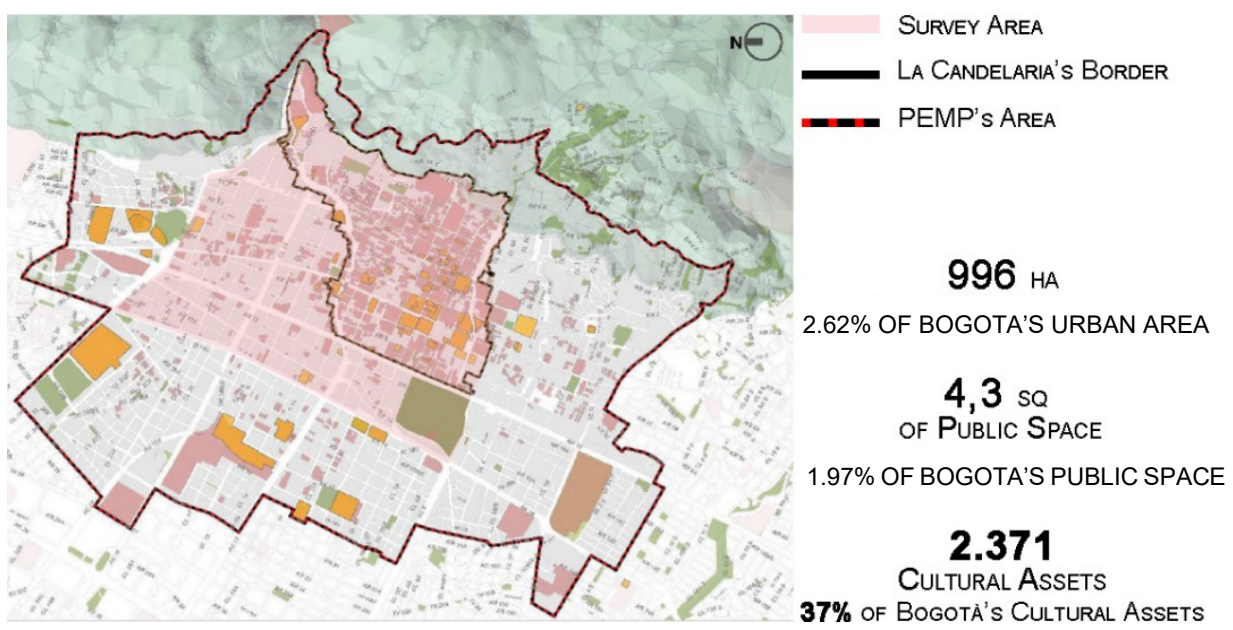

Figure 1: Urban and territorial context: Bogotà's cultural assets.

Urban cultural movements here include Barcú (since 2014) and La Feria Odeón (since 2011), both organized within the art week of Bogotá in the locality of La Candelaria. The first is an international cultural festival that combines the historical scenery of the district with different artistic events (plastic art, theater music, urban art, workshops, gastronomy, etc.) and takes from 25,000 to 30,000 visitors. The festival aims to bring art and people closer together and recover the ownership of the neighborhood, showing the power of culture "as a driver for integration, development, transformation and creativity". The events take place between calle (narrow street) 9 and 10 (carrera secunda and third est), in 14 houses and 21 galleries, also extending to the night ("Noches de Barcú"). The Feria Odeón is an alternative to the traditional artistic festival model with a strong interpenetration between architectural space and artistic performances. The building where all this takes place was regenerated in 2011 and has great historical-architectural value: first, it was the seat of the old Cinema Odeón (1940), then of the Teatro Popular of Bogotá, and now of Espacio Odeón. The visitor flow has an impact on the socio-economic level of the sector through a virtuous circle between the demand for services and products and the quality of the commercial appeal [31]-[33]. Another important event is Bogotá ArteCircuitos (BAC), Fundación Arteria's program shared with Cámara de Comercio, IDARTES and Invest in Bogotá. Since 2014, BAC has taken place one Saturday a month and has 26 art circuits (galleries, museums, foundations, institutions and independent spaces) distributed in six urban areas including the colonial center. It is a strategy for strengthening cultural industry within the city to support social integration and sustainable urban development [34].

\subsection{Zamboni district and new strategies for culture}

Bologna is taking part in the ROCK project (Regeneration and Optimisation of Cultural heritage in Creative and Knowledge Cities, www.rockproject.eu), financed through the H2020 program (SC5-21: Cultural Heritage as a driver for sustainable growth), which involves the university and municipality working together to identify common cultural goals and actions. ROCK works on historic city centers and, in particular, on the underused cultural hotspots, through the action of Cultural Heritage and its values as collective property and 
"common good", to promote their effective regeneration and adaptive reuse and an innovative, collaborative and systemic approach, drafted on seven selected "Role Model" cities and tested in three replicator cities (Bologna is one of them). It develops the integration of the creative city (creativity as a strategic factor for sustainable development) and knowledge city (knowledge-based economy); spaces (their uses and users) and key policy issues, to guarantee accessibility to Cultural Heritage and create cohesion and a sense of belonging to places; and different actors, places of Cultural Heritage value and systems (at a local and European level) connected by an innovative circular system headed for sustainable growth.

In particular, the ROCK project in Bologna is aimed at transforming the university area (Fig. 2) into a Sustainable Cultural and Creative District (Zamboni SCCD) by improving safety, mitigating social conflicts, attracting visitors and tourists, entrepreneurs and private investments, mixing conservation, new uses and technological solutions (microclimate control, security systems, innovative lighting solutions, digitalization and augmented reality). The actions involve cultural facilities of the Zamboni district (Porticoes, University Libraries, University Museums and other important spaces like the Opera House and Piazza Verdi), creating new interfaces with the city and the communities by temporary or permanent transformations and encouraging an unconventional use of culture to generate new tangible and intangible Cultural Heritage expressions. The porticoes, as a unique spatial experience of the city, will be enhanced with technological solutions developed by technological partners; plus, actions in the area foresee the definition of a new lightscape, the design of permanent micro-regeneration interventions, ephemeral events engaging creative professionals, industries and associations, coordinated by the Municipality of Bologna integrating culture, creativity, urban regeneration and social inclusion. The University Libraries (BUB) and University Museums will take part in cultural routes with the creation of 'The City of Libraries' and the City of Museums. The first will provide alternative uses of libraries in the area (during evenings and holidays), exploiting public spaces (street, squares) for temporary and green events linked to cultural activities as well as creating virtual tours and events by using augmented reality, digitalizations and the ROCK data platform. The latter will revitalize this conflictual area of the city by exploiting its economic role and becoming the catalyst of city development and local economies. A strategy to reduce microcrime and drug problems, as well as social conflicts in the area, will involve the Opera House and Piazza Verdi Experimental activities: citizens and students will have the opportunity to

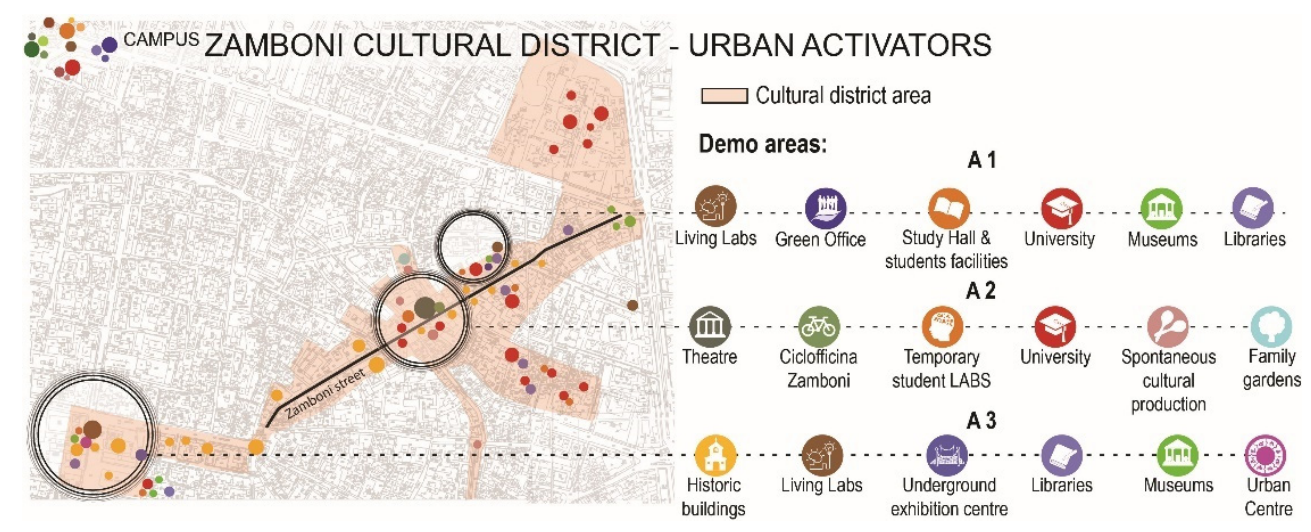

Figure 2: Zamboni cultural district: urban activators. 
approach music and concerts in the Respighi Foyer together with other different cultural experiences.

The approach applied in the Zamboni district uses Heritage Living LABs (U-Lab model referenced to heritage) to establish a working method based on a collaborative approach for the creation of urban heritage communities, in order to deliver urban-heritage-led regeneration.

\section{CONCLUSION}

The two case studies describe the will to pursue a common strategy for urban regeneration and social inclusion, based on knowledge and the active use of cultural heritage, as well as the conscious participation of citizens. The aim of this work was not to reduce the comparison between the two case studies to a list of similarities, but to exalt the crossing-cutting nature of the applicability of political action based on culture as strategy.

Any transformation of a city has its roots in well-targeted knowledge-conveying actions undertaken by weaving closely together all the potential and/or useful skills that can be derived from university research into the sciences and the arts, as well as relating to political and administrative matters, entrepreneurship and the third-sector. These knowledge-channeling actions are at the basis of an ongoing renovation of a city, and reinforce the creative actions dealing with cultural heritage. The experimental processes implemented and enacted in these two case studies are geared towards transforming data, initiatives, experiences and the cultural exchange of ideas and relationships into knowledge. This creates an active flow that is necessary to support the collaboration provided by the inhabitants to the city-wide processes of social and economic development [1].

\section{REFERENCES}

[1] Boeri A., et al., Culture as primary political action in city governance: three key concepts and ten policies to start with. CPCL EU, (0), 2018.

[2] Sennett, R., Costruire e Abitare. Etica per la città, Feltrinelli: Milano, 2018.

[3] UNESCO, Convention for the Safeguarding of the Intangible Cultural Heritage, Paris, 2003.

[4] Albrecht B. \& Magrin A., Esportare il Centro Storico, Rubbettino: Catanzaro, 2013.

[5] ICOMOS, Washington Charter 1987. Charter for the Conservation of Historic Towns and Urban Areas, Washington DC, 1987.

[6] UNESCO, Recommendation on the Historic Urban Landscape, Paris, 2011.

[7] ICOMOS, The Paris Declaration on Heritage as a Driver of Development, Paris, 2011.

[8] UNESCO, The Hangzhou Declaration. Placing Culture at the Heart of Sustainable Development Policies. Culture: Key to Sustainable Development, Hangzhou, 2013.

[9] United Nations, New urban agenda. Presented at United Nations Conference on Housing and Sustainable Urban Development (Habitat III), Quito, 2016.

[10] Steen, K. \& Van Bueren, E., Urban Living Labs. A living lab way of working, Amsterdam Institute for Advanced Metropolitan Solutions, Delft University of Technology, 2017.

[11] Steen, K. \& Van Bueren, E., The defining characteristics of urban living labs. Technology Innovation Management Review, 7(7), pp. 21-33.

[12] Francesconi, A. \& Cioccarelli, G., Prefazione. Organizzare i Distretti Culturali Evoluti, Franco Angeli: Milano, pp. 11-26, 2013.

[13] Calvino, I., Le Città Invisibili, Mondadori: Milano, 2016. 
[14] Bossio, S.N., Mancuso, F., Storchi, S. \& Toppetti, F., Dialoghi sullo spazio pubblico fra Europa e America Latina-Espacio público diálogos entre Europa y América Latina, ALINEA: Perugia, 2013.

[15] Carrión, F., Los centros históricos en la era digital. Iconos. Revista de Ciencias Sociales, 20, pp. 35-44, 2004.

[16] Arendt, H., Vita activa La condizione umana, Bompiani: Milano, 2017.

[17] Francesco, R., Contro l’identità, Laterza: Rome, 2007.

[18] EL TIEMPO, Esta será la transformación de la carrera 7. a con la peatonalización, www.eltiempo.com/bogota/obras-de-peatonalizacion-en-la-carrera-septima-78870. Accessed on: 17 Apr. 2017.

[19] IDPC, El PEMP, una construcción colectiva. Alcaldía Mayor de Bogotá D.C., idpc.gov.co/recuperacion-integral-del-centro-historico/.

[20] Dilorenzo, P. \& Stefani, E., Università e Città. Il ruolo dell'università nello sviluppo dell'economia culturale delle città. Presented at Conferenza dei Rettori delle Università Italiane, Rome, 2015.

[21] Bergamaschi, M. \& Castrignanò, M., La Città Contesa. Popolazioni urbane e spazio pubblico tra coesistenza e conflitto, FrancoAngeli: Milano, 2014.

[22] Saldarriaga Roa, A., Bogotá Siglo XX: Urbanismo, Arquitectura y Vida Urbana. Alcaldía Mayor de Bogotá, Departamento Administrativo de planeación Distrital: Bogotá, 2000.

[23] Barón Leal, L.A., La Carrera Séptima: Entre el Parque y la Plaza; Álbum de fotografías, Alcaldía Mayor de Bogotá: Bogotá, 2012.

[24] Ceccarelli, F. \& Cervellati, P.G., Da un palazzo a una città: La vera storia della moderna Università di Bologna, Il Mulino: Bologna, 1987.

[25] Tolomelli, A., Castelli, E., Scandurra, G. \& Tancredi, L., Memorie di uno spazio pubblico: Piazza Verdi a Bologna, CLUEB: Bologna, 2011.

[26] IDCP, PRTC. Plan de Revitalización del Centro Tradicional de Bogotá, Instituto Distrital de Patrimonio Cultural: Bogotà, 2015.

[27] Observatorio de Culturas, Carrera Séptima, un recorrido por la historia y la cultura. Bulletin no. 22, 2014.

[28] U-LAB report, Opendata Comune di Bologna, dati.comune.bologna.it/node/3506.

[29] Molina Londoño, L.F., et al., Ospinas 75 años, urbanismo, arquitectura, patrimonio, Bogotá: Ospinas \& Cia., 2008.

[30] Bogotá tiene un nuevo centro histórico; ARCADIA, www.revistaarcadia.com/ noticias/articulo/nuevo-centro-historico-bogota-instituto-distrital-de-patrimoniocultural-rendicion-de-cuentas/61039. Accessed on: 6 Dec. 2016.

[31] Barcú Así Somos, BARCÚ, www.barcu.com/asi-somos/.

[32] Barcú, la feria que busca ser un fiesta. Periódico Arteria, www.periodicoarteria.com/ barcu-quiere-ser-fiesta.

[33] El Edificio, Espacio Odeón, www.espacioodeon.com/el-edificio/.

[34] Proyectos transversales para la difusión, formación y circulación de las artes plásticas y visuales y la cultura. Bogotá Arte Circuito, www.fundacionarteria.org/. 